\title{
ROLE OF THE MUSLIM CONCEPT OF CHASTITY IN THE CONTEXT OF THE CULTURAL CLASH OF VALUES
}

ABSTRACT. Katarzyna Sadowa, Role of the Muslim concept of chastity in the context of the cultural clash of values, edited by Z. Drozdowicz and S. Sztajer, "Człowiek i Społeczeństwo" vol. XLI, Poznań 2016, pp. 163-176, Adam Mickiewicz University Press. ISSN 0239-3271.

In the modern, globalised world where the clash of different cultures' values is more and more visible, the conflict between Western culture and Islam seems to be most common. In this analysis, the author focuses especially on the Muslim concept of chastity and its actual role in the contexts of such a cultural conflict. At first, the author explains the problem of the cultures' clash, then she characterizes the Islamic concept of chastity and its particular value for Muslims. The main theme of publication is the analysis of chosen media messages regarding the call for combating non-approved Western rules by promoting living in accordance with the concept of chastity and ghayra.

Katarzyna Sadowa, University of Wroclaw, Faculty of Law, Administration and Economics Centre of Oriental Law Research, ul. Szamarzewskiego 89AB, 60-568 Poznań, Poland, e-mail: katarzyna. sadowa@gmail.com

"The underlying problem for the West is not Islamic fundamentalism. It is Islam, a different civilization whose people are convinced of the superiority of their culture and are obsessed with the inferiority of their power. The problem for Islam is not the CIA or the U.S. Department of Defence. It is the West, a different civilization whose people are convinced of the universality of their culture and believe that their superior, if declining, power imposes on them the obligation to extend that culture throughout the world" ${ }^{1}-$ so

${ }^{1}$ S. Huntington, Clash of Civilizations, New York 1966, pp. 217-218. 
wrote Samuel Huntington in his seminal work Clash of Civilizations, which pointed out that the main threat for the contemporary world may come not from the political or economic conflicts, but from the cultural and civilizational ones. Within the present publication I would like to analyse the problem of the actual problem of the cultural values of the West and of the Muslim world clashing in the globalised world, in the context of the concept of chastity promoted in the Islamic culture, which constitutes one of the forms of responding to the expansion of the unacceptable western values by the Muslims and a chance to maintain their identity.

According to the Polish PWN dictionary, globalization constitutes a "process consisting among other things in the increase of the volume of international trade, intensification of the movement of capital, people and technology, as well as the blurring of cultural differences."2 For the sake of the present analysis, I would like to focus on the impact of globalisation on different cultures. Nowadays, the intensification of globalisation processes is indisputable, mainly due to technological processes. When it comes to the main channels for transmitting certain trends, which aspire to be mass trends, a key role is played by the Internet and the media - the press, radio, $\mathrm{TV}$ as well as cinematic and musical productions. It seems easy to spot that essentially all these channels of transmission constitute products of the western world; and the domination of the trends - American or European - in the messages transmitted through these channels is also easily discernible. While any attempt at singling out some actual "global values" common to all cultures would not be warranted, an expansionist tendency of the western world seems easily recognised - it consists of trying to impose western values on the rest of the world and pretending to constitute a universal culture. ${ }^{3}$ This is clearly visible, for instance, when it comes to the concept of human rights, the principle of gender equality, or some other standards which are not supposed to be breached, concerning for instance the age of maturity, prohibition of polygamy, etc., which are generally fully accepted in Western countries. In general terms, these values are perceived by the western world as so "basic" that their validity should not be constrained to Europe or America, but that it should achieve a universal, global dimension. In practice, this obviously proves impossible, as some of the European standards stand in contradiction to the values of other cultures - for instance the Muslim culture, which allows

${ }^{2}$ http://sjp.pwn.pl/szukaj/globalizacja.html [access: 27.12.2015].

${ }^{3}$ Cf. e.g. K. Jędrzejczyk-Kuliniak, Globalizacja - wyzwanie czy zagrożenie dla tożsamości muzułmanów?, in S. Chazbijewicz, M. Turowski, K. Skarbek (eds), Islam. Religia a dylematy obywatelstwa i wykluczenia, Wrocław 2012, pp. 181-192. 
for polygamy, ${ }^{4}$ a low age of sexual maturity, ${ }^{5}$ as well as for an unequal legal position of men and women. ${ }^{6}$ At the same time, western attempts to impose its own rules on - among others - representatives of the Islamic culture are visible, but accompanied, on the other hand, by expressions on the part of the Muslims living in European countries of the will to maintain their own identity, leading to the emphasis of their own distinctiveness, which turn at another level into counter-attempts at imposing their own norms and values (expressed for instance by the imposition of sharia spheres in European cities, or the drive to legalise sharia law in Europe). ${ }^{7}$ The conflict between the two cultures, strengthened by globalisation processes, and especially migrations, ${ }^{8}$ becomes increasingly more visible, especially in Europe. In the context of the value clashes outlined above, Muslim migrants (as well as converts) becoming permanent residents of European states may assume two courses of action: Express some degree of obedience leading to the assumption of some basic western values (allowing for the eradication or even assimila-

${ }^{4}$ Polygyny is allowed: a Muslim can have up to four wives at the same time: "And if you fear that you will not deal justly with the orphan girls, then marry those that please you of [other] women, two or three or four. But if you fear that you will not be just, then [marry only] one or those your right hand possesses. That is more suitable that you may not incline [to injustice]." Quran, IV:3.

${ }^{5}$ There are divergent views with respect to the age of sexual maturity among the different scholars and Muslim schools. Some consider maturity to be reached at 15, while others think the age of maturity to be 12 for males and 9 for females. The Sunnis tend to generally assume that males mature at 18 and females at 17; while according to the Lebanese doctrine of Ja'fari the age of consent allowing for marrying is 9 for boys and 15 for girls. Cf. M.A. Syed, The Position of Women in Islam. A Progressive View, New York 2004, p. 28; J.J.A. Nasir, The Status of Women under Islamic Law and Modern Islamic Legislation, Boston 2009, pp. 57-59.

${ }^{6}$ For example, the testimony of two women is equal to that of one man, women tend to inherit at half the rate of men, and Muslim women are not allowed to marry non-Muslims, while only Muslim men are allowed to have more than one spouse.

${ }^{7}$ Cf. e.g. http://www.dailymail.co.uk/news/article-2019547/Anjem-Choudary-Islamic-extremists-set-Sharia-law-zones-UK-cities.html, access: December 2015.; http://www. pipelinenews.org/2011/oct/10/islamic-sharia-law-in-germany-holland-britain.html [access: 27.12.2015].

${ }^{8}$ According to a report of the Pew Research Center there were 44,1 million Muslims living in Europe in 2010, which amounted to 6\% of the European population. In selected countries the percentages ran as follows: Great Britain 4.6\%; Germany 5.0\%; Holland 5.5\%; Belgium 6\%, Sweden 4.9\%, Switzerland 5.7\%. Cf. Pew Research Center, The Future Global Muslim Population Projections for 2010-2030, Washington 2011, report available at: http://www.pewforum.org/files/2011/01/FutureGlobalMuslimPopulation-WebPDF- Feb10. pdf [access: 27.12.2015]. 
tion), or quite to the contrary, to empathically reject laws contradicting the sharia, relying on their own values (which leads to isolation). My analysis and observations lead to the conclusion that in recent years the latter option has gained primacy - the desire to maintain their own identity among Muslim minorities has intensified, leading to the rejection of those Western values which prove inconsistent with Muslim culture, and another more decisive rejection over all European trends. One of the areas of Muslim culture, which is supposed to play a significant role in this "conflict of values" and which leads to the maintenance of identity, is deeply rooted in the religion, tradition and culture of Islam - the concept of chastity.

What constitutes a cornerstone of the concept of chastity in Islam is the complete prohibition and the lack of acceptance of extramarital sexual relations. Zina (adultery) constitutes one of the main sins against God. The gravity of this deed is attested by the fact that it belongs to the category of crimes hudud, ${ }^{9}$ i.e., qur' anic crimes, for which the holy book itself prescribes an austere punishment - following the second verse of the twenty-fourth sura, the culprits should receive a 100 lashes each: "The [unmarried] woman or [unmarried] man found guilty of sexual intercourse - lash each one of them with a hundred lashes, and do not be taken by pity for them in the religion of Allah, if you should believe in Allah and the Last Day. And let a group of the believers witness their punishment." ${ }^{10}$ However, the second source of sharia law (sunna) goes one step further - in cases when adultery has been committed by people living in marriage, stoning to death is supposed to be the prescribed punishment instead of lashes: "Ubadah bin As-Samit narrated that the Messenger of Allah said: 'Receive from me (this revelation), receive from me (this revelation). Allah has ordained a way for those women (unmarried females who committed adultery). When an unmarried man, commits adultery with an unmarried woman, they should receive one hundred lashes and be exiled for a year. If they (fornicate while they) were married, they shall receive hundred lashes and be stoned to death.' Reported by Muslim." "11 Additionally, among the hudud actions there is also the crime of the "false accusation of adultery" - qadhf. Remarkably, in order to prove zina, four male witnesses are required, who are supposed to have witnessed the deed personally (it is also admissible for the guilty to

${ }^{9}$ Cf. e.g. R. Peters, Crime and punishment in Islamic Law, Theory and Practice from the Sixteenth to the Twenty-first Century, Cambridge 2005, pp. 53-64.

${ }^{10}$ Quaran, XXIV:2.

11 B. al-Maram,Hudud, Book 10, Hadith 1245, quote after: https://sunnah.com/urn/20 14920 [access: 27.12.2015]. 
plead or to use women's pregnancy as evidence). ${ }^{12}$ Should the accuser be incapable of proving adultery, the Quran proscribes a penalty of 80 lashes. ${ }^{13}$ This is clearly indicative of the high importance of the prohibition of extramarital sexual relations in Islamic law. There are additional interconnected commands, prescriptions and customs, obedience to which is supposed to guarantee maintaining chastity and excluding Zina. In this context, a very special role is played by the institution of marriage - on the one hand, constituting the fundamental social unit, and on the other, assuming elements of a civil contract, legalising sexual relations among its parties. ${ }^{14}$ Further guarantees protecting the chastity are supposed to be provided by limiting the possibilities for the different sexes to intermingle - a woman deciding to leave the house should do so under the guardianship of the male maharam, in principle a close male relative, who is supposed to protect her from direct contacts with strange men - nomahram - that may result in sin. An important role is also played by a suitably modest female dress. ${ }^{15}$ Covering the hair and face, as well as avoiding provocative garments, i.e., close fitting and expressive of body shapes, is supposed to protect Muslim women from unwanted gazes on the part of men, thus precluding the formation of any

${ }^{12}$ Cf. M. Sadowski, Naskh - metoda usuwania sprzeczności w prawie islamu, in Wrocławskie Studia Erazmiańskie, vol. VIII, Wrocław 2014, pp. 70-71.

13 "And those who accuse chaste women and then do not produce four witnesses lash them with eighty lashes and do not accept from them testimony ever after. And those are the defiantly disobedient, Except for those who repent thereafter and reform, for indeed, Allah is Forgiving and Merciful. And those who accuse their wives [of adultery] and have no witnesses except themselves - then the witness of one of them [shall be] four testimonies [swearing] by Allah that indeed, he is of the truthful. And the fifth [oath will be] that the curse of Allah be upon him if he should be among the liars. But it will prevent punishment from her if she gives four testimonies [swearing] by Allah that indeed, he is of the liars. And the fifth [oath will be] that the wrath of Allah be upon her if he was of the truthful. Quaran, XXIV:4-9.

${ }^{14}$ Under sharia law marriage is devoid of a spiritual dimension, and it essentially boils down to a legal act amounting to entering a marriage contract: "Marriage under Muslim law is a contract for the purpose of legalising sexual intercourse and the procreation of children. It is purely a civil contract, the terms of which depend, within very wide limits, on the will of the consenting parties, and to the validity of which no religious ceremony is necessary.” M.D. Manek, A Handbook of Mahomedan Law, Bombay 1948), quote after: J.J.A. Nasir, The Status of Women under Islamic Law..., p. 31; J. Schacht, An introduction to Islamic law, Oxford 1982, p. 161.

${ }^{15}$ Cf. e.g. S. Islam'il Kaita, To Veil Or Not To Veil: An Overview Of Muslim Woman's Clothing, in E-Proceeding of the 2nd International Conference on Arabic Studies and Islamic Civilization 2015, Kuala Lumpur 9-10 March 2015, p. 82; https://theauthenticbase. wordpress.com/tag/duyooth/ [access: 27.12.2015]. 
sinful relations. An apparent pinnacle of the Muslim concept of chastity comes in the form of ghayra. ${ }^{16}$ Ghayra, "protectiveness," "justified envy," or "protective envy" should be expressed by every Muslim with respect to all the close subordinate ones (although this duty is sometimes extended to all the women of the umma). Thanks to the proper elements of ghayra, the man is supposed to make sure that Women do not engage in any sinful behaviour by way of exerting proper control. It is being claimed that this is supposed to serve the benefit of all Muslim women by way of protecting them from committing sins, which would allow them to avoid punishment in the afterlife. ${ }^{17}$ On the other hand, ghayra is also supposed to guarantee the maintenance of honour, which constitutes one of the prioritised aspects of Muslim culture. This mostly relates to the namoos ${ }^{18}$ variety of honour, i.e., one that is gender-dependent - it is the woman that attests to the man's namoos by her proper behaviour. In cases when the woman has committed a prohibited act which constitutes a breach of some chastity standards (having a subjective nature), this brings shame to her own namoos, as well as to the namoos of her male guardian, and in a collective sense to the namoos of the whole family. In consequence, the honour can only be restored by way of a proper punishment for the woman, which often leads to violence motivated by honour, or in extreme cases to "honour killings." Both the concept of chastity and "justified envy" seem to play a special role in the context of the cultural clash. Ghayra is supposed to constitute a form of remedy against the unacceptable Western trends - what comes under criticism includes such issues as the free intermingling of the sexes, ease of leaving the house by European women, unsuitable and provocative

${ }^{16}$ There are different ways of spelling, e.g. ghayra or gheerah. For the sake of the present article I assume the former, yet, the attached print-screens may contain the latter form.

${ }^{17}$ For further reading on the concept of ghayra Cf. e.g. D. Akbari, P. Tetreault, Honor Killing: A Professional's Guide to Sexual Relations and Ghayra Violence from the Islamic Sources, Bloomington 2014, p. 74; F. Barakatullah, Reviving our sense of Gheerah, in Al Mu'minaat Press, vol. 1, issue 7, February 2010; K. Sadowa, Ghayra i namus a zjawisko zbrodni "honorowych" w społecznościach muzułmańskich - zarys problemu, Wrocławskie Studia Erazmiańskie, vol. IX, Wrocław 2015.

${ }^{18}$ For further reading on the topic of honour namoos Cf. e.g. Cf. Namus, in D.G. Bates, People and Cultures of the Middle East, Just the Facts101, s.l., 2014; D. E. King, The Personal Is Patrilineal: Namus As Sovereignty, in Identities: Global Studies in Culture and Power, vol. 15, no. 3, London 2008, p. 319; http://askville.amazon.com/national-origin -wordnamus/AnswerViewer.do?requestId=39929558 [access: December 2015]; I. Cetin, Defining Recent Femicide in Modern Turkey: Revolt Killing, “Journal of International Women’s Studies” vol. 16, no. 2, January 2015. 
European clothes, social acceptability of sexual freedom, as well as the frequent use of social media such as Facebook, Twitter or Instagram by women. Interestingly, their criticism of the above-mentioned tendencies is usually disseminated by the very same social media which is supposed to allow for reaching a wider audience, especially of young people. Internet sites are increasingly inundated by various kinds of posts, notes, pictures, or the so-called memes, which criticise the western life-style as well as call on every Muslim to remember the duties stemming from having ghayra. For the most part, these messages are aimed at men, but one can also encounter such messages whose target is women. For the sake of the present publication I shall analyse some selected instances.

First among them is a note published on Facebook by an Indian public speaker, Nisar Nadiadwala, in August 201219; it was entitled "What is your Gerrah Index? Do you really Posess Gherrah?”

The range of the post is notable - 168 likes, and 119 shares as well as 23 comments, attest to the popularity of both the Author - followed by 9820 people - and of the note itself. In the introduction to the post, Nadiadwala refers to the sources in which the duty of ghayra is embedded; in the first paragraph he mentions Sa-'ad bin Ubadah'a (companion of Mohamed) as the role-model possessing the quality of "protective envy." In the second chapter, he relates to one of the hadiths constituting ghayra, according to which the Prophet had a dream featuring his visit to the Umara ibn Al-Khattaba palace in the heavens, where he witnessed a women washing herself, at which sight he retreats so as not to offend Umar's ghayra. ${ }^{20}$ The author of the note refers to the key figures living in the times of Mohamed, and thus he initially relates the roots not only of the very concept of ghayra but also of Islam as such. This is apparently supposed to underscore the importance of the sources from which the concept of ghayra is derived, which the Author cites as a noble virtue given by Allah himself.

In the subsequent part of the post, Nadiadwal wants to draw attention to the contemporary level of ghayra, and expresses criticism of the behaviour

${ }^{19}$ Cf. https://nisaaryusuf.wordpress.com/ [access: 27.12.2015].

20 “Narrated Abu Huraira: We were sitting with Allah’s Apostle, he said, 'While I was sleeping, I saw myself in Paradise. Suddenly I saw a woman performing ablution beside a palace. I asked, 'For whom is this palace?' They (the angels) replied, 'It is for Umar bin Al-Khattab.' Then I remembered 'Umar's ghira and went back hurriedly.' On hearing that, 'Umar started weeping and said,' Let my father and mother be sacrificed for you. O Allah's Apostle! How dare I think of my Ghira being offended by you?'” S. Al Bukhari, Book 87, no. 150, quote after: http://www.searchtruth.com/book_display.php?book=87\&translator $=1 \&$ start $=30$ [access: 27.12.2015]. 


\title{
What is your Gheerah Index? Do you really Posses Gheerah?
}

\author{
28 sierpnia $2012008: 44$ is
}

Sa'ad bin Ubadah was a sahabi. his gheerah was unmatched... If any of his wife sat on his horse he would never sell this horse.. If any of his wife sat on a camel he would make sure that he would slaughter his camel. He was a man of gheerah.. He would not tolerate any one to sit on the horse or camel on which his wife sat. His gheerah was admired. People honoured his gheerah so much that if he divorced any of his wives, no sahabi would marry that lady. RadiAllahu anhu. .Allah be please with him.

Gheerah is a noble asset. If any one possesses it then Allah has gifted him a noble trait. Look how our Prophet, peace be upon him, responded to Umar bin Khattab's gheerah. In his dream he was taken to a tour of Jannat. He was a huge white Palace. So beautiful that he thought it must be for him. But he was told that it was to be awarded to Umar Bin A Khattab. The Prophet decided to enter and have a look into it. But the moment he saw Umar's hoor was performing ablution he stepped out. He recalled the gheerah of Umar.

Look at our gheerah. Our women, our girls jump on any wall of namahram and click 'ike' and interact with them and search from them a spouse on their own, fall in and out of love, share personal informatios and chat at midnight hours, and yet we dont feel bad. Rather, millions of fathers don't even come to know that their daughters who prays five times have multiple affairs on the intemet. She chases good looking young men who sprout beards and update their status with a Qur'anic ayah or a borrowed quotation after every hour. For her, talking about deen to Namahram is not a fitnah.

A sahih hadith says.. A dayyus will not even smell the fragrance of paradise " Who is a dayyus? The higher category includes people who eam money by allowing their women to do prostitution. The lower category includes people who dont mind their women, daughters, sisters talking, chatting, dreaming, befriending Non mahrams.

Asma bint abu Bakr's husband was Zubair bin Awwam. He was also a man of gheerah. man who was counted among those ten Ashhar al mubashhara. The ten who got glad tidings of Jannah. His wife respected his gheerah and honoured it. Once she was walking on a hot sunny day, carrying a load of wood. The beloved Prophet, peace be upon him, was passing by on his camel and saw the lady labouring in hot sun. He offered his camel to carr her to her house. The noble lady who honoured her husband's gheerah refused. She recalled her husband's gheerah and preferred to walk in the hot sun carrying the load.

Many of our girls are harbouring sweet desires of being proposed by a young man and keep on visiting the profiles of young men. Do they not realise the gheerah of their future husband who would marry them thinking that they are noble girls? Isn't it a deception? That too in the name of deen, girls and boys interact with each other!

The Bani Israel's fitnah was women. It lead them to destruction and threw them down from the sight of Allah. Look at the Bible and note how the scribes have treated women. Multiple rapes, incests evrything is there in the religious book! This reflects their mentality. Even today the most vulgar and obscene films were introduced in Hollywood by the Bani Israels. They have compted the west.

Now it is the tum of Muslims to be tested. One cannot drag a Muslimah out of her hijab. So the approach is new. FACE BOOK. Be friend with boys and leam deen from them. Get impressed by his picture in beard. Follow his notes and shares. Be happy if he tags you. Ask him a question on deen. Get replies and then find out if he is married or not and what type of girl is he looking for. This is how fitnah initiates.

Nothing offers you seclusion like the silent lanes of cyber world. Sisters! shouldn't you be worried about your modesty when a young man tags you to his Islamic note? Why is he tagging you and not your wrinkled skinned and grey haired aunty? Does such question ever arise in your mind? If not, then you are a target in a game and the result is sure.. You will loose.

Author Nisaar Nadiadwala can be reached at nisaar_yusuf@yahoo.com

\begin{tabular}{l} 
Wh Lubiẹ to! $\rightarrow$ Udostẹpnij \\
188 osób lubi to. \\
118 ponownych udostẹpnień \\
\hline
\end{tabular}

Fig. 1

Source: https://www.facebook.com/notes/nisaar-y-nadiadwala/what-is-your-gheerah-index -do-you-really-posses-gheerah/417664251625032 [access: 27.12.2015]. 
of women - being especially disparaging when it comes to their use of the Internet (their browsing of sites belonging to strange men prohibited to them (nonmahram); the liking of their posts; looking for husbands on their own; constant falling in and out of love; sharing of personal information; chatting late into the night). What he considers even worse is the lack of negative reaction among the men of their kin. Nadiawal points out that many Muslims are probably unaware that their seemingly pious daughters engage in multiple romantic affairs online and conduct conversations with nonmahram, while seeing nothing sinful or evil in such actions. In order to emphasise the negative dimension of the lack of reaction on the part of the male guardians to the behaviour of women, the Author relates to the concept of dayooth, referring to a person that does not possess ghayra, which according to the sunna would preclude their ascension to heaven (Jannah) ${ }^{21}$ It is also remarkable that the Author makes a distinction between two categories of dayooth - the first is supposed to comprise men earning wealth through the prostitution of their women, while the second, lower category refers to persons showing indifference with respect to improper forms of female behaviour, such as the aforementioned chatting, befriending or having phantasies about nonmahram men.

After a cursory analysis of the contemporary situation from the vantage point of ghayra, Nadiadwala refers to another hadith constituting the duty of 'protective envy,' presumably to amplify the message and further emphasise the vitality of the discussed concept. ${ }^{22}$ The author praises the actions

21 "There are three at whom Allah will not look at on the day of Resurrection: (1) the one who disobeys his parents, (2) the woman who imitates men, and (3) the duyooth (a man who has no protective jealousy towards his womenfolk).” S. Al-Jaami’ As-Sagheer 3/74, hadith no. 3066, quote after: https://theauthenticbase.wordpress.com/tag/duyooth/ [access: December 2015].

${ }^{22}$ Hadith, to which the Author alludes, refers to the ghayra of a further companion of Mohamed - Az-Zubaira: “Narrated Asma' bint Abu Bakr: When Az-Zubair married me, he had no real property or any slave or anything else except a camel which drew water from the well, and his horse. I used to feed his horse with fodder and drew water and sew the bucket for drawing it, and prepare the dough, but I did not know how to bake bread. So our Ansari neighbors used to bake bread for me, and they were honorable ladies. I used to carry the date stones on my head from Zubair's land given to him by Allah's Apostle and this land was two third Farsakh (about two miles) from my house. One day, while I was coming with the date stones on my head, I met Allah's Apostle along with some Ansari people. He called me and then, (directing his camel to kneel down) said, 'Ikh! Ikh!' so as to make me ride behind him (on his camel). I felt shy to travel with the men and remembered Az-Zubair and his sense of Ghira, as he was one of those people who had the greatest sense of Ghira. Allah's Apostle noticed that I felt shy, so he proceeded. I came to Az-Zubair and 
of Asma, who refused the Prophet's offer of a ride on his camel in order to protect the gahyra of her husband. Nadiadwala's point seems to consist of drawing attention to what he considers the proper and expected behaviour of contemporary women, which does strongly deviate from this ideal. In further parts of the text, the Author comes back to the criticism of the actual behaviour of women who desire the advances of strange young men and constantly visit their profiles. Nadiadwala, aiming to inspire reflection, poses a rhetorical question whether they are aware of the ghayra of their future husbands, who would marry them being certain of their nobility. Would their actions then not constitute some kind of deception?

The author's highlighting of the negative role of women's transgressions against ghayra points further to the temptation (fitna $)^{23}$ for the 'children of Israel,' which brought them to damnation and moved them further from $\mathrm{Al}$ lah. Furthermore, he refers directly to the Bible and the many descriptions of rape and incest that it contains, which he considers to have had a detrimental effect on the mentality of the Jews, whom he also accuses of promoting the most obscene and vulgar films in Hollywood so as to corrupt the West. The dislike of the author for the Israelites is easily detectable.

In the final part of the note, Nadiadwala points out that the contemporary times are a test for Muslims, when nobody has the right to expect of Muslim women to drop the hijab, and that Facebook has become a new kind of threat. The author emphasises that the cyber-world is conducive to loneliness, and the post's closing remarks contain a series of rhetorical questions aimed at strengthening this message and shaking the addressees, i.e., Muslim women - "Sisters! shouldn't you be worried about your modesty when a young man tags you to his Islamic note? Why is he tagging you and not your wrinkled skinned and grey haired aunty? Does such a question ever arise in your mind? If not, then you're a target in a game and the result is sure. You will lose!”

said, "I met Allah’s Apostle while I was carrying a load of date stones on my head, and he had some companions with him. He made his camel kneel down so that I might ride, but I felt shy in his presence and remembered your sense of Ghira (See the glossary). On that Az-Zubair said, 'By Allah, your carrying the date stones (and you being seen by the Prophet in such a state) is more shameful to me than your riding with him.' (I continued serving in this way) till Abu Bakr sent me a servant to look after the horse, whereupon I felt as if he had set me free.” S. Al Bukhari, Book 62, no. 151, quote after: http://www.searchtruth.com/ book_display.php?book=62\&translator=1\&start=150 [access: 27.12 .2015 ].

${ }^{23}$ Fitna is a polysemic word, it does also assume different meanings in the Qu'ran. In the context of this particular text it is supposed to mean a desire for something forbidden, negative. Cf. e.g. http://islamqa.info/en/22899 [access: 27.12.2015]. 


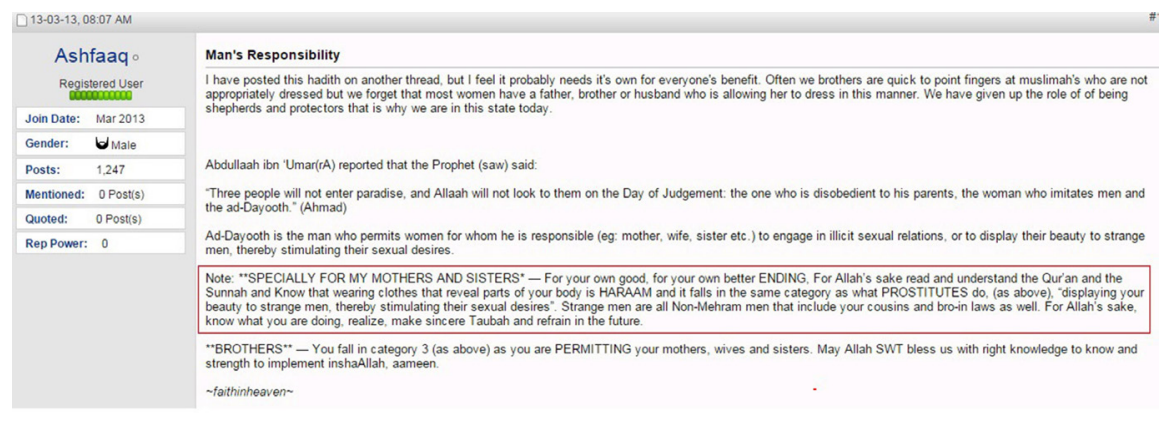

Fig. 2

Source: http://www.ummah.com/forum/showthread.php?357798-Man-s-Responsibility [access: 27.12.2015].

It is important to note that other Facebook posts relating to ghayra often directly criticise the western world ${ }^{24}$ as the source of negative influences, where immoral trends and sinful standards originate, which must be resisted, for instance, by recourse to "protective envy." Messages such as the one analysed here are certainly meant to cause reflection among the recipients, and perhaps even to provoke expressions of decisive opposition against the unaccepted western customs by relying on ghayra, remembering and practising it.

Posts on Internet fora constitute another form of expression addressed both to men and women. For the purposes of the present paper I shall analyse one of them, which was posted in March, 2013, and which has a harsh and clear message.

The author of the post, a Muslim, attempts mostly to highlight the male duty of ghayra. He mentions the tendency among Muslims to automatically point to the improper clothes of Muslim women, while forgetting that these women do have fathers, brothers or husbands, who are responsible for them. He points out that the role of shepherds seems to have faded away, which results in the current state (lacking ghayra) of the Muslim community. Following a line of thought like that of the previous note, the Author refers to the hadith stating what constitutes dayooth, explaining that it is committed by

${ }^{24}$ Cf. e.g. the post from June 26, 2013, which contains the statement of the Author that in the times of westernisation dayooth is perceived as a modern, liberal and moderate person, while possessing gheerah is seen as unhealthy envy, and those who possess it are seen as overly protective, controlling and dangerous. Cf. https://www.facebook.com/iamalmajiri/posts/650683058294069 [access: 27.12.2015]. 
every man who allows their women illicit sexual relationships or exhibiting their beauty to nonmahram. In the further part of his message he explicitly directs attention to Muslim women "especially for my mothers and sisters," in which it seems that he wants to shout: "For your own good, for your own better ending. For Allah's sake read and understand the Qur'am and the Sunnah, and Know that wearing clothes that reveal parts of your body is Haraam and falls into the same category as what prostitutes do." The Author specifies further that the strange nonmahram men includes cousins, and brothers-in-law, and calls for women to realise "for God's sake" what they are guilty of doing and that they should repent for their sins and avoid committing any of them in the future. The closing sentences are directed to the Muslim brothers, whom the Author warns that by allowing their women to behave improperly they become dayooth. The Author of the post wants to reach both Muslim women and men, and he makes the extreme comparison of improper behaviour to prostitution, which is supposed to strengthen the impact. Guilt for the present state of umma (lacking proper levels of ghayra) is ascribed both to women, behaving improperly and sinfully, as well as to men, who have lost the ability to take care of women subordinate to them.
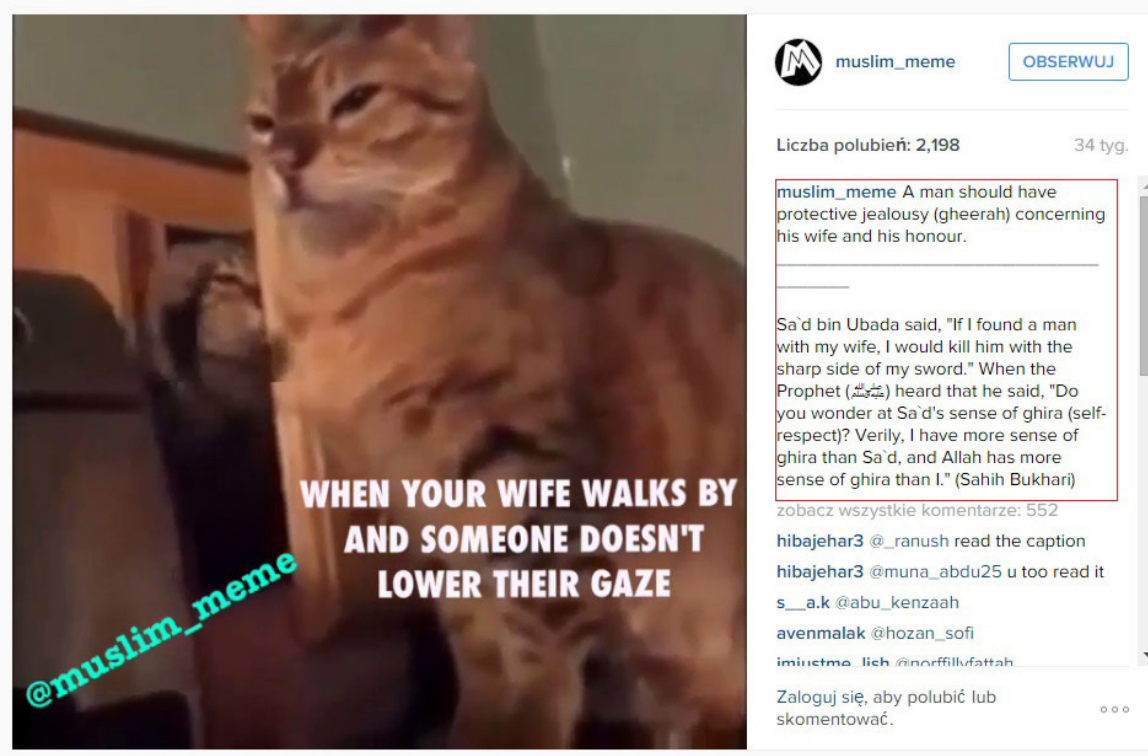

Fig. 3

Source: https://www.instagram.com/p/0PJDQKnHWu/ [access: 27.12.2015]. 
Another form of messaging aimed at promoting the awareness of the duties of ghayra comes in the form of memes published on Instagram, which are then tagged and commented upon. For instance, one of them presents a popular short clip of a cat hitting another with a paw. The meme is branded by the inscription: "When your wife walks by and someone doesn't lower their gaze," thus, the sense depicted by the clop is supposed to be an ironic commentary on how one should act under such circumstances. The author of the post - using the nick-name muslim_meme - emphasises in the description that the possession of ghayra with respect to the wives and to one's own honour remains a duty of every man. So as not to be merely funny, the Author of the post adds reference to one of the hadiths referring to the "protective envy." The ever-increasing number of likes - 2224 as of December $27^{\text {th }}, 2015$ - proves a high outreach, probably thanks to the use of a funny movie.

A different message, also posted on Instagram, constitutes a direct criticism of western societies. The picture features a cover of the biography of a well-known footballer, which as the Author contends is a reminder of why he is blessed by being a follower of Islam. He states rhetorical questions, which express his outrage at the partner of the woman on the cover allowing for such an explicit depiction of his wife on the cover of a book. He asks where the dignity and "protective envy" of the man has gone. The Author of the post expresses deep dissatisfaction and resentment, which is addressed to men - nowadays lacking ghayra - as well as women - lacking purity and humility (hayaa). Finally, he emphasises that it is not only this particular picture that constitutes a problem, and that there is much more going on in contemporary societies - he asks rhetorically "How can we be comfortable in such an environment that questions our hayaa?” The post does certainly constitutes an expression of rebellion and fundamental criticism on the part of the Author of certain European standards, with which he cannot, or at least wants not to be, in agreement with, and thus makes appeals at a change of mind and "proper" pure behaviour.

The analysed messaging constitutes only select examples of a class of similar posts available online. The fact that they are posted in English points to the conclusion that they are mostly aimed at Muslims (and not necessarily only Muslims) living in the West. The Authors aim at turning their attention to the negative influences of western culture, and they also call for remembering of the duties of ghayra and of recreating it within oneself. It seems therefore that the concept of chastity in Islam constitutes one of the principal areas used nowadays by the Muslim world to oppose and criticise 


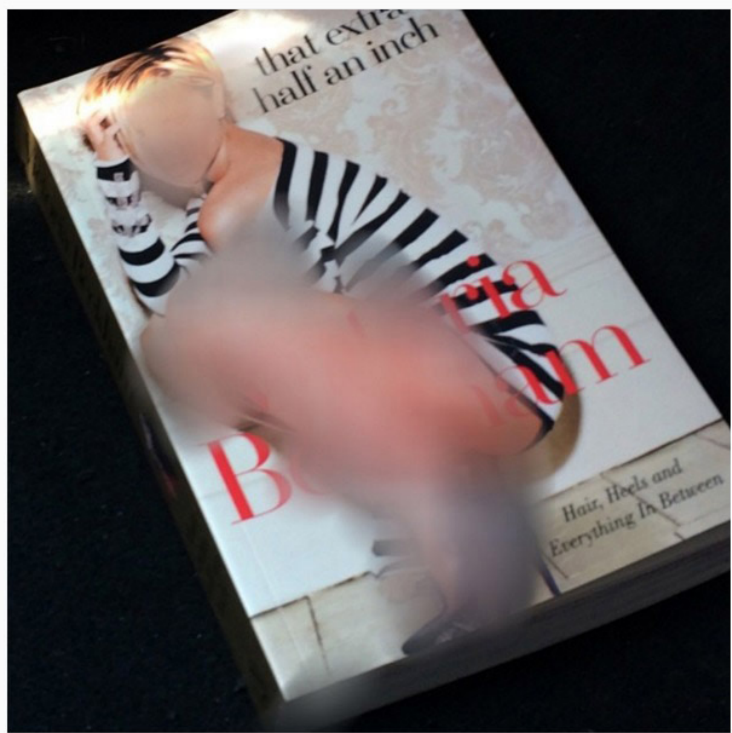

famous football player. Really as I look at the cover of this book. It reminded me why I am blessed with Islam. How can a man, a husband, a father let his wife pose in such a way? I mean where is honor? Where is the dignity? Where is your sense of protective

jour sense of protective ghayrah one who does not care if non mahram men approach his wife, mothe sister or daughter; a dayooth can't enter jannah. But to the women, too. Can't believe fahsha; I once read the

immorality has reached new heights that we don't see it wrong anymore? Where is hayaa? Not just talking about this photo in particular but yknw the many other things going on in our society. How can we be comfortable in such

can we be comfortable in such
environment that questions our hayaa etc \#gheerah \#ghayrah \#dignity \#dayus \#aintriskinqmviannab

Zaloguj się, aby polubić lub skomentować

Fig. 4

Source: https://www.instagram.com/p/qtblSPG43z/?tagged=gheerah [access: 27.12.2015].

the unwanted western influences. In this context, it remains important to consider the Muslim woman, who becomes the greatest victim of the cultural clash between Islam and the West. As the woman is the main one responsible for maintaining the chastity, when such standards are broken (by clothing, contacts with strange men, etc.), then in the context of the radicalisation of Muslim circles and the strife for maintaining identity, there is an increased risk of experiencing violence by Muslim women as a form of punishment. An increasingly more intensive clash between the western and Muslim values becomes dangerous not only for those values (one of them will have to give way sooner or later), but also runs the risk of an increase of violence motivated by "honour," whose extreme kind comes in the form of murder. It seems therefore worth considering what boundaries to set for the "protective envy" so that it does not assume the appearance of an overly-protective or even murderous one. Is everything in the hands of academics? 